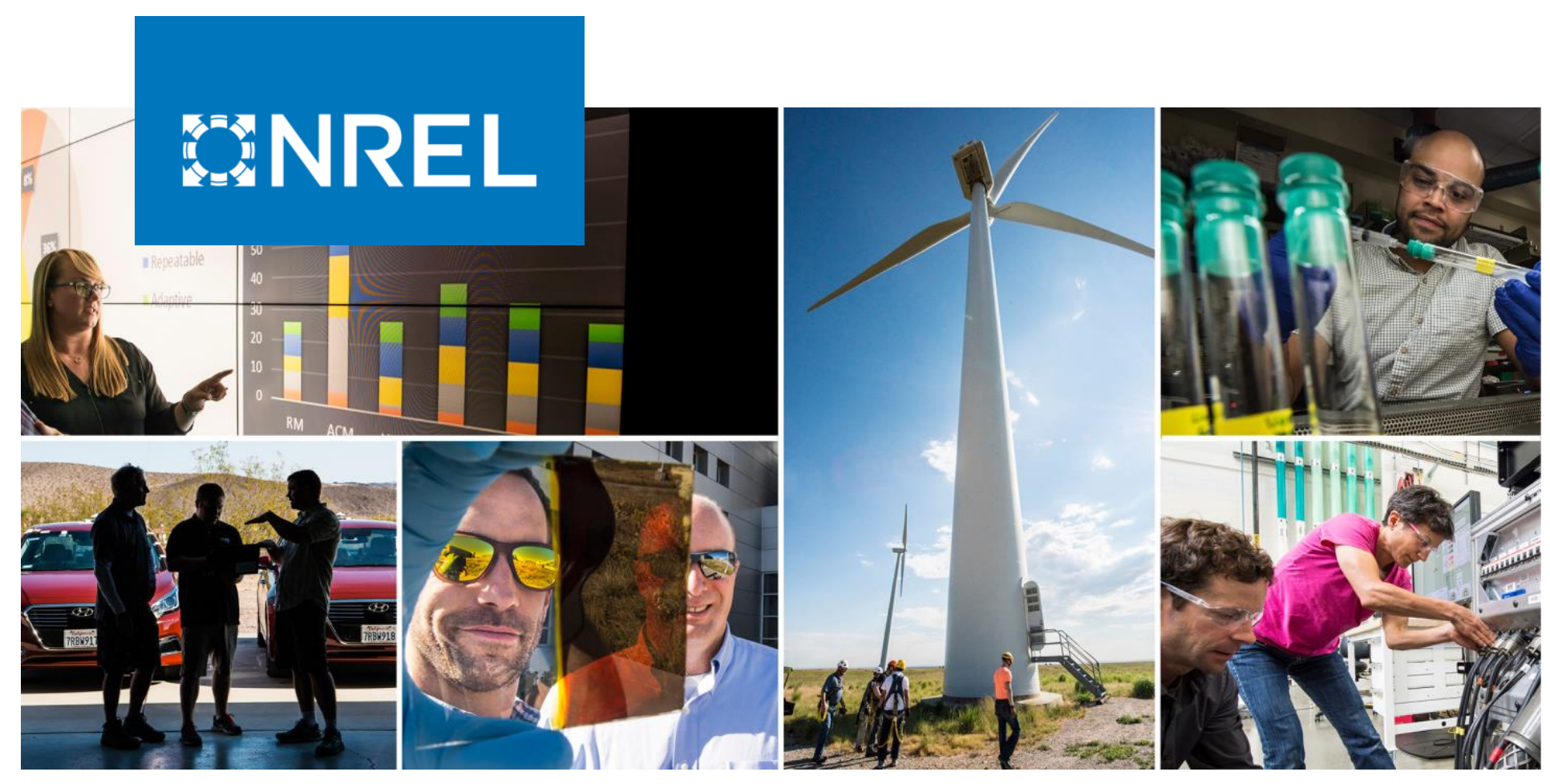

\title{
Collaboration to Enable Higher Penetrations of Solar Power Generation Using the Natural Gas Pipeline System for Energy Storage
}

Cooperative Research and Development Final Report

CRADA Number: CRD-14-00567

NREL Technical Contacts: Kevin Harrison and Nancy Dowe

NREL is a national laboratory of the U.S. Department of Energy Office of Energy Efficiency \& Renewable Energy

Operated by the Alliance for Sustainable Energy, LLC

This report is available at no cost from the National Renewable Energy Laboratory (NREL) at www.nrel.gov/publications.

\section{Technical Report}

NREL/TP-5B00-79694

April 2021 


\section{GHREL}

Collaboration to Enable Higher Penetrations of Solar Power Generation Using the Natural Gas Pipeline System for Energy Storage

Cooperative Research and Development Final Report

\section{CRADA Number: CRD-14-00567}

NREL Technical Contacts: Kevin Harrison and Nancy Dowe

\section{Suggested Citation}

Harrison, Kevin; and Nancy Dowe. 2021. Collaboration to Enable Higher Penetrations of Solar Power Generation Using the Natural Gas Pipeline System for Energy Storage: Cooperative Research and Development Final Report, CRADA Number CRD-14-00567. Golden, CO: National Renewable Energy Laboratory. NREL/TP-5B00-79694.

https://www.nrel.gov/docs/fy21 osti/79694.pdf.

NREL is a national laboratory of the U.S. Department of Energy Office of Energy Efficiency \& Renewable Energy Operated by the Alliance for Sustainable Energy, LLC

This report is available at no cost from the National Renewable Energy Laboratory (NREL) at www.nrel.gov/publications.

Contract No. DE-AC36-08G028308
Technical Report

NREL/TP-5B00-79694

April 2021

National Renewable Energy Laboratory 15013 Denver West Parkway Golden, CO 80401

303-275-3000 • www.nrel.gov 


\section{NOTICE}

This work was authored [in part] by the National Renewable Energy Laboratory, operated by Alliance for Sustainable Energy, LLC, for the U.S. Department of Energy (DOE) under Contract No. DE-AC36-08GO28308. Funding provided by U.S. Department of Energy Office of Energy Efficiency and Renewable Energy Solar Energy Technologies Office. The views expressed herein do not necessarily represent the views of the DOE or the U.S. Government.

This work was prepared as an account of work sponsored by an agency of the United States Government. Neither the United States Government nor any agency thereof, nor any of their employees, nor any of their contractors, subcontractors or their employees, makes any warranty, express or implied, or assumes any legal liability or responsibility for the accuracy, completeness, or any third party's use or the results of such use of any information, apparatus, product, or process disclosed, or represents that its use would not infringe privately owned rights. Reference herein to any specific commercial product, process, or service by trade name, trademark, manufacturer, or otherwise, does not necessarily constitute or imply its endorsement, recommendation, or favoring by the United States Government or any agency thereof or its contractors or subcontractors. The views and opinions of authors expressed herein do not necessarily state or reflect those of the United States Government or any agency thereof, its contractors or subcontractors.

This report is available at no cost from the National Renewable Energy Laboratory (NREL) at www.nrel.gov/publications.

U.S. Department of Energy (DOE) reports produced after 1991 and a growing number of pre-1991 documents are available free via www.OSTI.gov.

Cover Photos by Dennis Schroeder: (clockwise, left to right) NREL 51934, NREL 45897, NREL 42160, NREL 45891, NREL 48097, NREL 46526.

NREL prints on paper that contains recycled content. 


\section{Cooperative Research and Development Final Report}

Report Date: March 24, 2021

In accordance with requirements set forth in the terms of the cooperative research and development agreement (CRADA), this document is the final report described in the statement of work (SOW), including a list of subject inventions, to be forwarded to the U.S. Department of Energy (DOE) Office of Scientific and Technical Information as part of the commitment to the public to demonstrate results of federally funded research.

Parties to the Agreement: Southern California Gas Company - A Sempra Energy Utility

CRADA Number: CRD-14-00567

CRADA Title: Collaboration to Enable Higher Penetrations of Solar Power Generation Using the Natural Gas Pipeline System for Energy Storage

Responsible Technical Contact at Alliance/NREL:

Kevin Harrison | Kevin.Harrison@nrel.gov

Nancy Dowe | Nancy.Dowe@ nrel.gov

Vahan Gevorgian | Vahan.Gevorgian@ nrel.gov

John Lewis $\mid \underline{\text { John.Lewis@ @nrel.gov }}$

Greg Stark | Greg.Stark@nrel.gov

Name and Email Address of POC at Company:

Ronald L. Kent $\mid \underline{\text { RKent @ semprautilities.com }}$

Sponsoring DOE Program Office(s):

Office of Energy Efficiency and Renewable Energy (EERE), Solar Energy Technologies Office (SETO)

Joint Work Statement Funding Table showing DOE commitment:

\begin{tabular}{|c|c|}
\hline & $\begin{array}{c}\text { NREL Shared Resources } \\
\text { a/k/a Government In-Kind }\end{array}$ \\
\hline Year 1 & $\$ 450,000.00$ \\
Year 2, Modification \#2 & $\$ .00$ \\
Year 3, Modification \#3 & $\$ .00$ \\
Year 4, Modification \#4 & $\$ 199,997.00$ \\
\hline TOTALS & $\$ 649,997.00$ \\
\hline
\end{tabular}




\section{Executive Summary of CRADA Work}

This unique project explored one possible solution for photovoltaic (PV) generation to become a reliable and dispatchable energy resource similar to conventional baseload fossil fuel electricity generation. Solar power generation is a renewable resource that varies naturally from day-to-day as well as seasonally. To use solar power as a baseload generation asset requires a flexible storage system that can recover power on both a daily and seasonal basis. Converting solar power to natural gas (i.e., first to hydrogen and then to methane) and having access to utilityscale storage in the natural gas network has the potential to make solar power generation a baseload asset. This will:

- Increase the net energy yield from solar resources by increasing the effective capacity factor and maximize the energy produced during the assets' lifetimes:

- Improve the economics of energy storage for solar project developers, thereby accelerating the deployment of new solar generation;

- Reduce the impact of increasing solar penetration on congestion of the electrical transmission system by shifting power delivery in time using the gas pipeline network for long-duration storage;

- Reduce the impact of increasing solar generation on electrical distribution system control; and

- Offer alternative revenue sources for solar power generation beyond electricity including: hydrogen $\left(\mathrm{H}_{2}\right)$ production for stationary fuel cells and fuel cell electric vehicles, conversion of carbon dioxide $\left(\mathrm{CO}_{2}\right)$ to methane $\left(\mathrm{CH}_{4}\right)$ as a direct drop-in replacement for fossil natural gas use, and transmission as high volumetrically-dense $\mathrm{CH}_{4}$ for use in transportation, heating, power generation, chemical production or conversion back to $\mathrm{H}_{2}$ at the point of use.

Additional work was added to this CRADA in modification 4 having a primary objective to characterize the performance of the electrolyzer, Southern California Gas (SoCalGas) bioreactor and balance of plant to demonstrate production of renewable natural gas (RNG) from renewable $\mathrm{H}_{2}$ and $\mathrm{CO}_{2}$ using single-cell, self-replicating organisms. The additional scope of work allowed researchers to ramp up gas flowrates and pressure of the system over the designed range to grow the cells and begin to show the load-following capabilities of this anaerobic gas fermentation process. These activities enabled the research team to predict system performance at much greater scales; namely 10's of mega-watts (MWs) of electrolyzer nameplate capacity.

\section{$\underline{\text { Key Outcomes }}$}

- Developed a detailed startup, shutdown (daily \& extended) and safety processes for the bioreactor system.

- Started mapping the operational envelop of the bioreactor in terms of pressure ramp rates, temperature control, reactor level, mixing power, response time, gas input ranges and methane production rates.

- Demonstrated the system response to changes in input gas flow rates, ability for control system maintain system $\mathrm{pH}$, pressure and temperature fluctuations during microbe growth and production activity phases.

- Developed sufficient monitoring, and control software to achieve stable and safe operation of the system. 


\section{$\underline{\text { Funding \& Work Breakdown }}$}

The original CRADA funding included $\$ 450 \mathrm{~K}$ from both SoCalGas and the DOE SETO starting in 2015. The work and funding were divided equally between Analysis and Experimental tasks, which were led by the following people at NREL.

\section{Original CRADA SOW}

- Task 1a: Analysis - Model Development - Vahan Gevorgian

- Task 1b: Analysis - Gas Storage - Greg Stark

- Task 2: Experimental - Design and build physical test system - Kevin Harrison

- Task 3: Experimental - Testing - Nancy Dowe

- Task 4: Experimental - Model validation - Nancy Dowe and Kevin Harrison

- Task 5: Analysis - Valuation of Gas Energy Storage for Grid Applications - Greg Stark

Modification 4 of the CRADA provided matching funds from both SoCalGas $(\$ 200 \mathrm{~K})$ and the Energy Systems Integration Facility (ESIF) facilities \& infrastructure operating budget due to its importance and value to DOE/NREL and was designated a high impact project with work starting in FY18. In addition to the matching high impact projects funds from the ESIF, \$250K was provided to heat trace and insulate the bioreactor and nutrition skids to enable year-round operations.

\section{CRADA SOW Modification 4}

Experimental tasks 1 - 5 were completed by Nancy Dowe and Kevin Harrison whereas the modeling and analysis completed under Task 6 was led by John Lewis and Mark Ruth.

- Task 1: Develop Test Plan to Characterize Bioreactor Steady-State Performance

- Task 2: Execute Relevant Steady-State Test Plan at Bench Scale and Produce Inoculum

- Task 3: Execute Steady-State Test Plan on SoCalGas Bioreactor System

- Task 4: Develop Test Plan for Variable Mode of Bioreactor Operations

- Task 5: Execute Test Plan for Variable Mode of Bioreactor Operations

- Task 6: Modeling and Analysis 


\section{Original CRADA - Summary of Research Results}

\section{Task 1: Model development - PEM Fuel Cells for Grid Applications}

Task 1a: Develop a dynamic simulation model from solar electrical generation to hydrogen, methane, storage and back to electricity.

Storing the electricity generated by PV systems as molecules requires the use of conversion technologies such as water electrolyzers to produce $\mathrm{H}_{2}$ and bioreactor systems and a $\mathrm{CO}_{2}$ source to produce renewable methane; also known as RNG. Deploying high temperature fuel cells can efficiently convert the chemical energy stored in the RNG back to electricity during periods of high demand.

Such conversion processes have never been implemented at industrial scale in the U.S., and require careful evaluation and analysis of costs, benefits, and operational impacts of the concept. Modeling tools for the full energy conversion cycle need to be developed and validated through experimental testing. Figure 1 describes the how to use the existing natural gas network as a near limitless energy storage medium for solar baseload power generation (proposed energy flow is depicted by green arrows). Other options shown below for using hydrogen and natural gas are possible, but outside the proposed scope (e.g., fuel cell electric vehicle fueling) of this task.

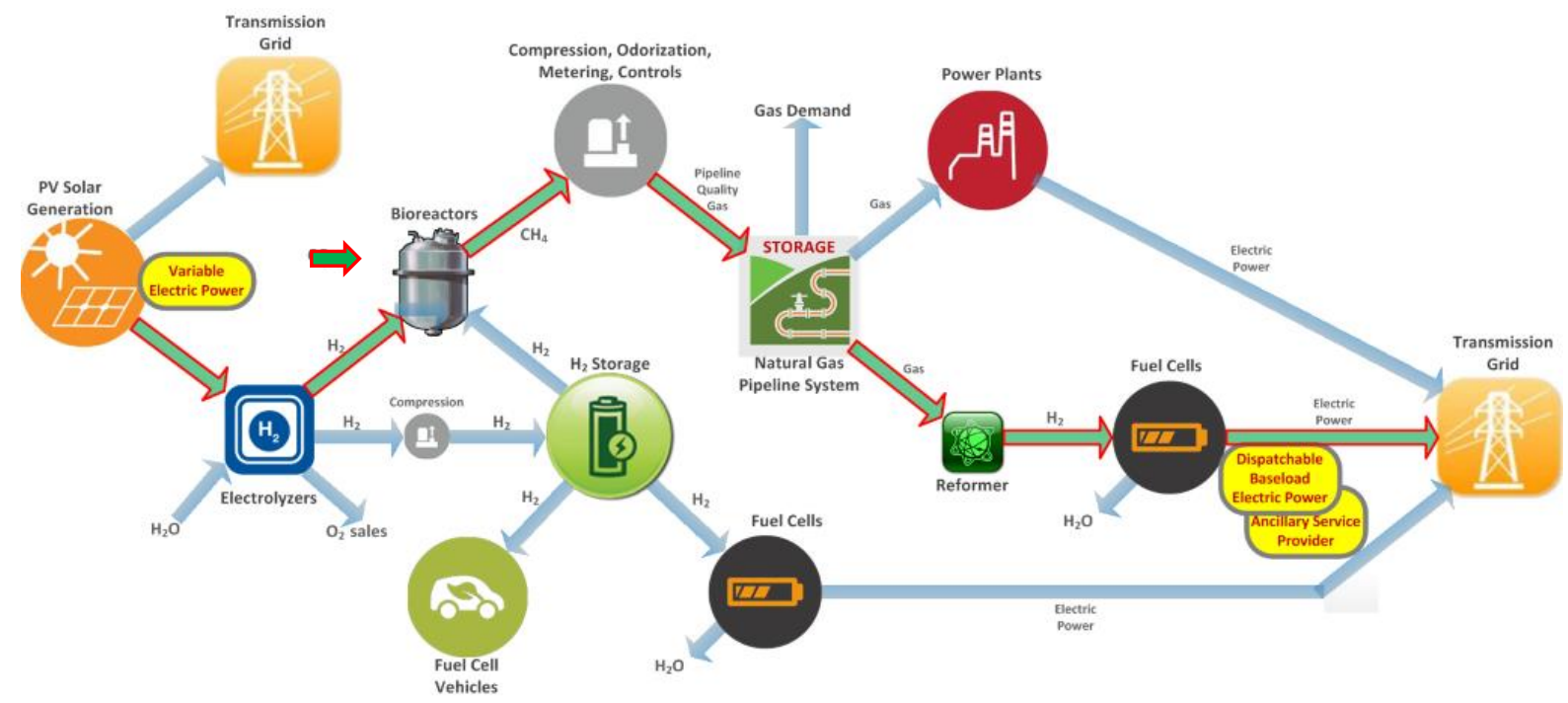

Figure 1. The concept of PV-Gas-Storage-Grid system.

The objectives addressed in the task report are:

Develop dynamic model of a comprehensive polymer exchange membrane fuel cell (PEMFC) system from gas to grid;

- Propose auxiliary control strategy of fuel cell system to provide the grid support (e.g. primary frequency control, automatic generation control (AGC) and voltage control);

- Simulate the dynamic system model and investigate the performance of the auxiliary controller;

- Analyze the preliminary simulation results of the dynamic model. 


\section{Summary from Task 1 Report}

Dynamic modeling, control, ancillary control strategies and simulation of the PEMFC system connected to power grid were investigated in this report. A detailed electrical model of $42 \mathrm{~kW}$ PEMFC system was developed in MATLAB/SIMULINK simulation platform using SimPowerSystems toolbox. The detailed system model includes reformer, PEM fuel cell stack, power conditioning unit with controller, ancillary service controller, distribution system and transmission system. This model used the capabilities of the PEMFC system to provide active and reactive power control, frequency responsive controls, AGC, voltage control. The detailed electrical model can be used to understand short term transient and dynamic characteristics for the system but is not applicable for longer term simulations due to slower execution.

A simplified system model developed to enable long-term simulations of the proposed technology can be used in a grid integration study. This model does not use a detailed representation of the inverter (DC-to-AC) and DC-to-DC power converter. Instead, the power conditioning block is modeled using programmable current source.

Simulations using both models were conducted, and we showed that many ancillary servicerelated controls can be implemented in PEMFC based plant. The models can be used for some preliminary analysis of specific project sites, but economic value of such analysis might be questionable.

Based on preliminary modeling results, PEM fuel cell generation in combination with steam reformers (besides being a reliable form of baseload power) demonstrated excellent controllability, and is capable of providing the whole spectrum of ancillary service to the grid:

- Various forms of active power control (inertia-like response, primary frequency response, AGC, spinning and non-spinning reserve, etc.)

- Voltage/reactive power/power factor control

- Voltage fault ride-through capability

The value of each service must be evaluated though economic simulations in future stages of the project. Only few ancillary service markets currently exist in the California Independent System Operator (CAISO), and if economical, FC generation can act as a bidder in all of them.

\section{Task 1b: Gas Storage}

The gas storage tasks defined in the original agreement are bulleted below but were not completed. Instead, two new projects were developed as a result of this initial power-to-gas CRADA. 


\section{Summary of the Two New Projects}

Project 1: Linking the electrical and natural gas networks is key to the power-to-gas concept. A new technical service agreement (TSA-19-16315), funded by SoCalGas, was established to reveal opportunities for low-cost wholesale electricity to power electrolyzer systems and enable earlier adoption of gas storage in the natural gas network. The objective of the new TSA was to understand the current regulatory barriers, cost barriers, and identify opportunities offered by various pathways to access wholesale power prices for economically viable hydrogen production that might be available to SoCalGas.

\section{Key Takeaways}

- As expected, the capacity factor for the electrolyzer must be very high (>96\%).

- Develop and document the steady-state model of gas storage system

- Integrate the model in PLEXOS software system

- Develop simulation scenarios for CAISO system (base case, solar penetration levels, dispatch scenarios, etc.)

- Provide solar data sets for selected PV sites

- Given the very high capacity factor for the electrolyzer, the hydrogen production cost is strongly correlated to the average location marginal price of electricity.

- Energy cost and California's low-carbon fuel standard credits (\$180/MT, $\sim 2 / \mathrm{kg} \mathrm{H} 2)$ are the drivers of the resulting hydrogen production cost $(\sim 5 / \mathrm{kg} \mathrm{H} 2)$ under best-case conditions.

Project 2: A second project was executed using a technology commercialization funding opportunity for techno-economic analysis encompassing design, planning, and optimal hydrogen-natural gas blend ratios and injection locations, considering gas composition and any codes and standards applicable to hydrogen blending that bear on pipeline longevity, reliability, and safety. The project was still underway at the time of writing.

\section{Original CRADA Tasks}

\section{Task 2: Design and Build Physical Test System}

The task objectives are listed and details of their completion are summarized below.

- Assist SoCalGas in RFP and procurement process for bioreactor and steam methane reformer systems - Completed, see below

- Develop the test plan-Completed, see below for start of work with results summarized in CRADA Modification 4, Task 1

- Design and build a small-scale test system - Completed, bench-scale results summarized in CRADA Modification 4, Task 2

- Provide low temperature fuel cells and electrolyzers, PV array simulator, PV inverter, grid simulator - Completed, see below.

- Provide components and design a customized supervisory control and data acquisition (SCADA) system for the SoCalGas bioreactor and nutrient skid - Complete, see below. 
The SoCalGas bioreactor was designed by the engineering firms Burns and McDonnell (Kansas City, MO) and Plant Services (Houston, TX). SoCalGas contributed additional funds ( $\sim 3 \mathrm{M})$ to have both the bioreactor and nutrient dosing skids designed, fabricated and delivered to NREL these funds were in addition to the matching funds for this CRADA.

NREL assisted in the design of the system and with the safety review during multiple Process Hazard Analysis (PHA) meetings conducted at NREL. The bioreactor and nutrient skids were fabricated by Accelerated (Woodlands, TX) and delivered to NREL for installation by NREL personnel. NREL took part in the factory acceptance of the bioreactor and nutrient dosing skids at Accelerated before shipment to NREL.

Pacific Northwest National Laboratory (PNNL) was set to supply the steam methane reformer (SMR) that would transform the RNG from the bioreactor back to hydrogen to show the full roundtrip possibilities of this concept. While not formally documented in this CRADA statement of work, NREL visited PNNL to support the startup of the control system that NREL designed and built for their SMR system.

During the visit to PNNL, it was determined the SMR was not a practical addition for the pilotscale demonstration at NREL so the research plans were dropped. In particular, the SMR start-up procedure took many hours of attended operation by an engineer and was incompatible with the hazardous location near the hydrogen and bioreactor systems. Without significant modifications, the SMR system would not meet the electrical classification (Class 1, Division 2, Groups B/D) requirements to be located out on the ESIF pad near the bioreactor, compressors, and hydrogen storage systems.

A number of activities were completed and documents created by NREL to enable the safe startup of the bioreactor system in August 2019.

1. A detailed PHA was completed and modifications made to the system design to address elements considered moderate to high risk.

2. Multiple Safe Work Permits (SWPs) were developed to cover system start-up, normal operations, media preparation, safe handling of ammonium hydroxide and sodium sulfide, inoculation, media additions, and analytical procedures.

- A sample of the documentation created is shown here.

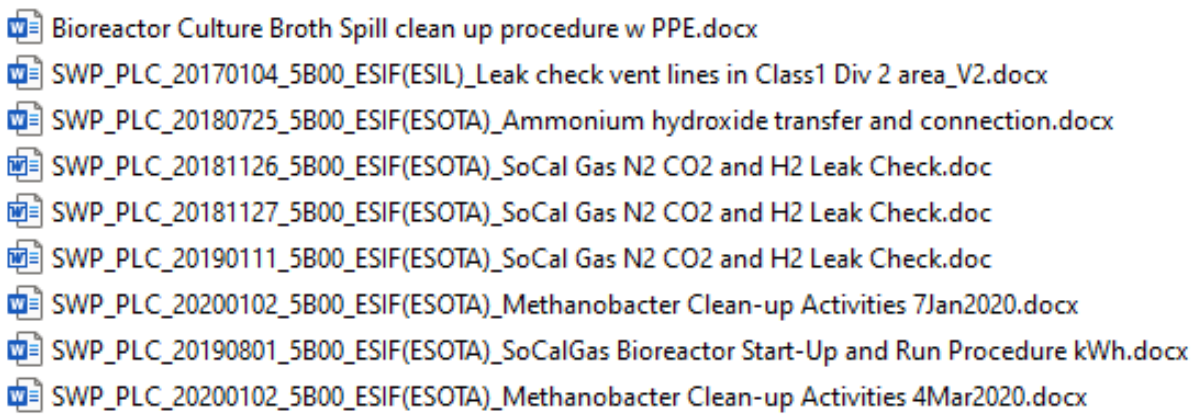

3. Calibration, programming and verification of all sensors, dosing and circulation pumps were completed as part of the commissioning list. 
4. A valve configuration checklist for each valve position needed for start-up, shutdown, and extended shutdown periods was created.

5. Labeling all valves, piping, vessels, and devices with tags was completed.

6. Detailed preparation instructions were completed for hydrogen sulfide, nutrients, selenium tungsten and handling procedures for ammonium hydroxide and anti-foam.

7. Multiple pressure leak tests on vessels, piping and seal pots were completed using both pressure decay and handheld leak check devices using hydrogen gas in the system (multiple files with different dates shown above).

8. Calibration of the gas chromatograph with known quantities of methane $\left(\mathrm{CH}_{4}\right)$, hydrogen $\left(\mathrm{H}_{2}\right)$, carbon dioxide $\left(\mathrm{CO}_{2}\right)$ and hydrogen sulfide $\left(\mathrm{H}_{2} \mathrm{~S}\right)$ was completed.

9. Validation of the control systems, alarm, and faults including the following systems; heating, cooling, gas flow rate, pressure control, agitation control, bioreactor level control, and confirmed readouts from all sensors and pumps.

10. Cleaning and characterizing liquid levels detection of bioreactor and waste vessels prior to inoculation and start-up was completed.

11. Loading the bioreactor with nutrients prior to inoculation with organisms.

12. Test plan included activities to grow the culture in the 700L pilot-scaled bioreactor from roughly $10 \%$ at inoculation (produced in Task 2 of CRADA Modification 4) using low ( $25 \%$ of rated) gas flows and incrementally increasing pressure from 2 to 10 bar. Full pressure operation to 18 bar was not completed at the time of this report.

13. Additional ESIF budget was used (beyond the Mod. 4, High Impact Project funds) to design and install heat trace, insulation, and protective cladding on both the bioreactor and nutrient skids to enable winter operations.

NREL's low-temperature PEM electrolyzer system was upgraded from $125 \mathrm{~kW}$ to $250 \mathrm{~kW}$ between the start of the project in 2014 and delivery of the bioreactor system to NREL in 2018. The bioreactor system was originally designed for the gas output from a $125 \mathrm{~kW}$ electrolyzer stack or roughly $2.5 \mathrm{~kg} \mathrm{H}_{2}$ per hour ( $\sim \mathrm{lb} / \mathrm{hr}$ from Section 2.3.1 of the Design Basis). The higher gas output from the higher power $(250 \mathrm{~kW})$ stack was not an obstacle. NREL has $\mathrm{H}_{2}$ storage at 3000 psig available to the bioreactor rather than direct feeding from the stack. A pressure reducing regulator was used at the input of the bioreactor to step down the pressure from the $\mathrm{H} 2$ storage tanks to the design point of $260 \mathrm{psig}$.

PV Simulation: NREL's AC-to-DC power supplies are capable of very high slew rates (i.e., power changes) to simulate power from varying photovoltaic array - this is known as the PV array simulator. In the case of the variable gas flow test plan and experimental work conducted under CRADA Modification 4, Tasks 4-5, simulation connection to a PV array was completed by varying gas flows using pneumatically-controlled variable position valves at the input of the bioreactor. This way the electrolyzer, compressor systems and other research activities could be conducted simultaneously while the bioreactor was connected to the hydrogen storage system. 
NREL, working with Electrochaea, SoCalGas and Spectrum Automation Control, designed and built a control system with the following functionality;

- Manual and automatic control of valves and pumps

- Monitoring of all sensors including gathering gas constituent data from the gas chromatograph

- Pressure monitoring and control using proportional integral derivative (PID) loops that automatically adjust valves to maintain a specific pressure setpoint

- Temperature monitoring and control using a PID loop, cooling pump and proportional valve to control coolant flow

- Manual and automatic gas flow control using PID loops

- Manual and automatic bioreactor liquid level control using a PID loop

- Alarm and fault setpoint, monitoring and reaction to out-of-bounds conditions

- Manual setting of agitation rotational speeds

- Manual control of the main culture recirculation pump

- Monitoring and control of high foaming events that automatically dose anti-foam and cycle valves

- Manual and automatic time-based control of dosing pumps that add ammonium hydroxide, sodium sulfide, selenium tungsten and a mixture of salts and minerals (i.e., nutrients)

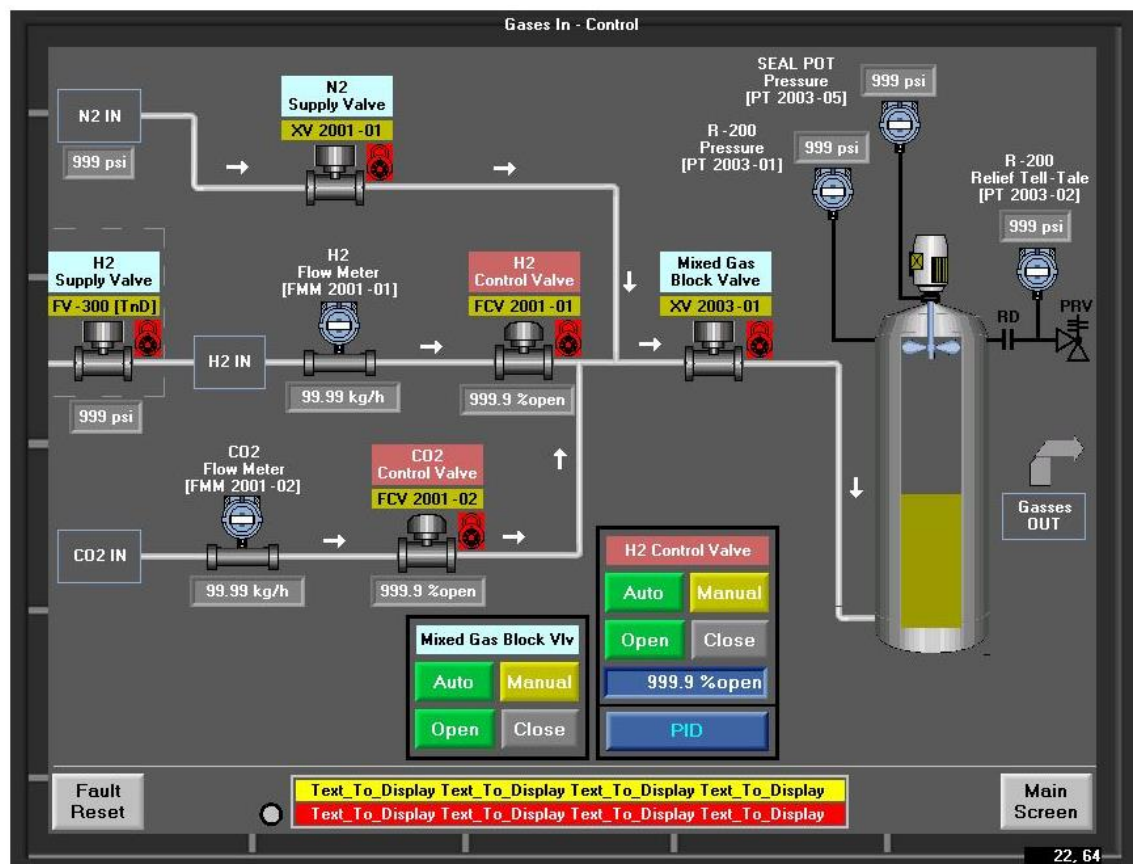

Figure 2. Example of control system interface of gas flow inputs 


\section{Task 3: Testing}

- Supervise day-to-day operation and testing of the system - Complete, see below

- Collect and process experiment data - Complete, see below

- Conduct data analysis - Complete, see below

- Prepare the test report - Complete, see below

Initial start-up consisted of running minimal gas flow rates of $0.6 \mathrm{~kg} / \mathrm{hr} \mathrm{H} 2$ and $3.2 \mathrm{~kg} / \mathrm{hr} \mathrm{CO} 2$ and a bioreactor pressure up to 75 psig or 5 bar to establish the biocatalyst and determine baseline $\mathrm{CH}_{4}$ production levels. The initial gas flow rates and pressure were $25 \%$ of the maximum design point of the SoCalGas bioreactor. Agitation rates were varied to show the effect on $\mathrm{CH}_{4}$ production. Error! Reference source not found. shows how increasing agitation rates significantly improved conversion of $\mathrm{H}_{2}$ and $\mathrm{CO}_{2}$ to $\mathrm{CH}_{4}$. The figure also shows that when agitation rates were repeated, as was the case with $20 \mathrm{~Hz}$ and $25 \mathrm{~Hz}$, the $\mathrm{CH}_{4}$ concentration and conversion level reproduced. We achieved a maximum of $92 \% \mathrm{CH}_{4}$ in the product gas and $99 \%$ conversion at $40 \mathrm{~Hz}$, which is $67 \%$ of the maximum agitation rate of $60 \mathrm{~Hz}$ or $360 \mathrm{rpm}$. These results suggested that maximum agitation will be needed to achieve $>98 \%$ conversion to $\mathrm{CH}_{4}$ when the gas flows to the bioreactor are increased to the design basis of $2.3 \mathrm{~kg} / \mathrm{hr} \mathrm{H} \mathrm{H}_{2}$ feed rate.

During start-up, we also monitored the growth of the culture by measuring the cell density, or optical density (OD), using a spectrophotometer at a wavelength of $610 \mathrm{~nm}$. Figure 4 shows how the culture grew during the first 20 days of operation, in which we averaged about 6 hours of run time each day before shutting down for the night. The culture doubled about every 3 days for the first 10 days then started to slow down and reach a steady state around $25 \mathrm{OD}$. The saw-tooth shape of the data is a result of the production of metabolic water which was removed along with some cells. Concentrated nutrients were added back to the bioreactor to replace nutrients lost from when the metabolic water was removed. Each time nutrients were added to the bioreactor, the culture was diluted slightly resulting in a lower OD. The culture would grow back to the steady-state OD and the process of removing water and cells and adding back nutrients started again. The process of growing the culture took nearly 100 hours of operation but is expected to go quicker if the bioreactor can be operated continuously.

During this period of operation, we finalized and documented our start-up and shut-down procedures, chemical mixing protocols, data acquisition and monitoring, and on-line controls. We operated the bioreactor for 250 hours of attended operation over 35 days. 


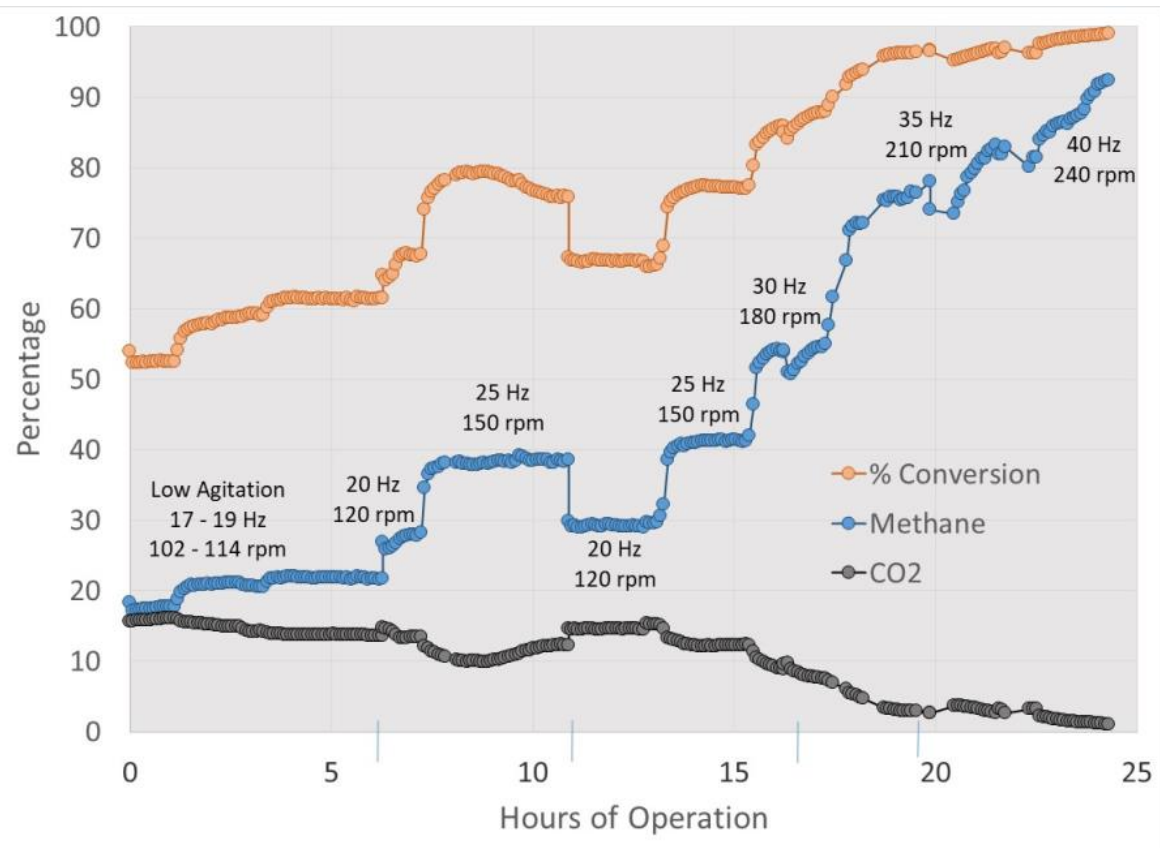

Figure 3. The concentrations of $\mathrm{CO}_{2}$ and $\mathrm{CH}_{4}$ and the percent conversion when the bioreactor agitation changes from $17 \mathrm{~Hz}(102 \mathrm{rprm})$ to $40 \mathrm{~Hz}(240 \mathrm{rpm})$. The bioreactor was run at a constant $0.6 \mathrm{~kg} / \mathrm{hr} \mathrm{H} \mathrm{H}_{2}$ and $3.0 \mathrm{~kg} / \mathrm{hr} \mathrm{CO}_{2}$ feed gas flow rates and $75 \mathrm{psig}$ pressure.

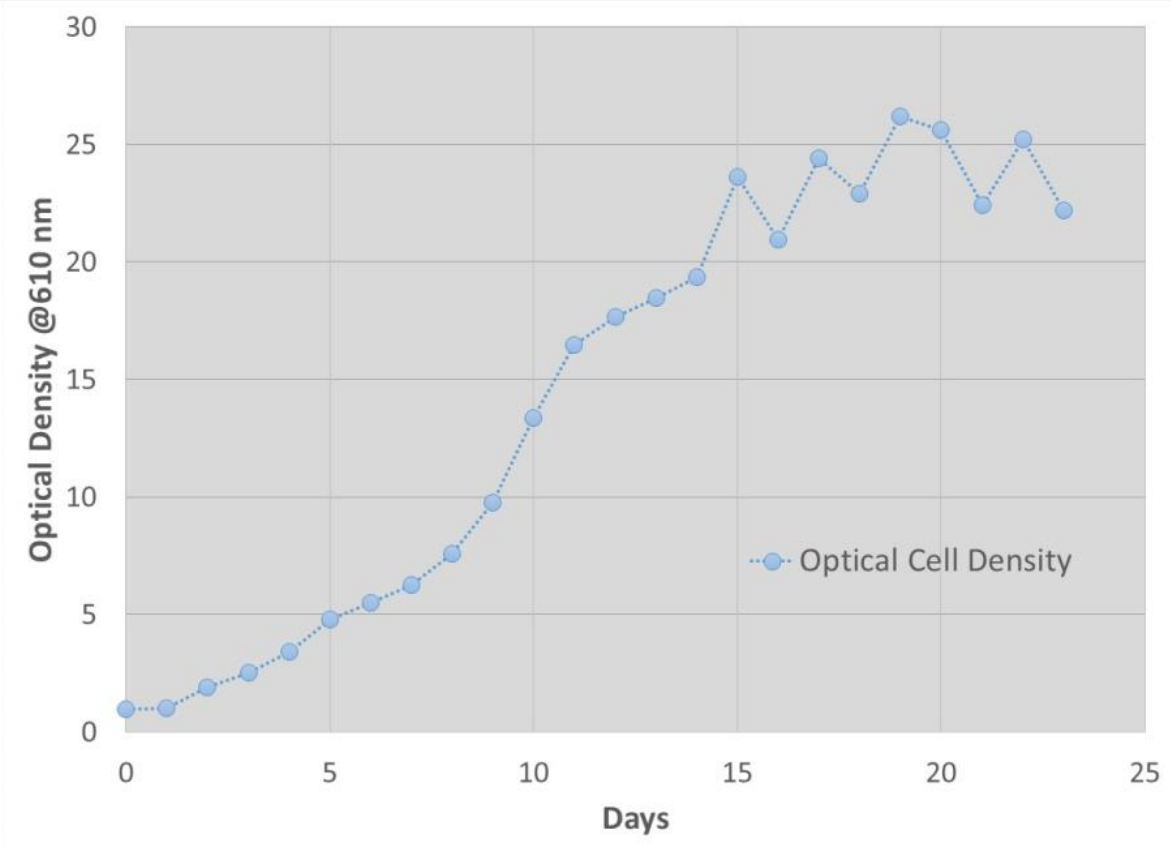

Figure 4. Cell growth profile during the first 20 days of operation (approximately 120 hours). Cell density was measured using a spectrophotometer at $610 \mathrm{~nm}$ wavelength. 


\section{Task 4: Model Validation}

- Calibrate and document the model using test data from Task 3

\section{Results}

Table 1. Model validation results for $700 \mathrm{~L}$ SoCal Gas bioreactor design basis and future $10 \mathrm{MW}$ system.

\begin{tabular}{|c|c|c|c|c|c|c|}
\hline & $\begin{array}{l}\text { Electrolyzer } \\
\text { Power (MW) }\end{array}$ & $\begin{array}{c}\text { H2 Flow } \\
\text { In } \\
(\mathrm{kg} / \mathrm{hr})\end{array}$ & $\begin{array}{c}\text { CO2 } \\
\text { Flow In } \\
\text { (MT/yr) }\end{array}$ & $\begin{array}{c}\mathrm{CH} 4 \\
\text { Produced } \\
\text { (scfm) }\end{array}$ & $\begin{array}{c}\mathrm{CH} 4 \\
\text { Produced } \\
\text { (MMBtu/yr) }\end{array}$ & $\begin{array}{c}\text { Water } \\
\text { Produced } \\
\text { (gpm) }\end{array}$ \\
\hline $\begin{array}{c}\text { SoCalGas } \\
700 \mathrm{~L} \\
\text { Bioreactor } \\
\text { Design Basis }\end{array}$ & 0.125 & 2.3 & 100 & 3.9 & 1900 & 0.05 \\
\hline $\begin{array}{c}10 \text { MW System } \\
\text { Model } \\
\text { Estimates }\end{array}$ & 10 & 180 & 7,500 & 270 & 145,000 & 3.5 \\
\hline
\end{tabular}

Burns \& McDonnell and Plant Services developed a design basis for the biomethanation system starting with NREL's electrolyzer capacity at the time $(125 \mathrm{~kW})$ and information gathered from Electrochaea $\mathrm{GmbH}$ and literature. A productivity of 6.5 grams of $\mathrm{CH}_{4} / \mathrm{L}-\mathrm{hr}$ was calculated using a spreadsheet model using the as-built volume of the bioreactor, including culture held-up in the balance of plant (e.g., heat exchanger, pump, and piping), and back-calculating the methane production capability from the $125 \mathrm{~kW}$ electrolyzer stack. The model validation results shown in the top row of Table 1 match the information from Burns and Plant Services design basis documents.

The same model parameters were used to calculate process flows for a $10 \mathrm{MW}$ electrolyzer system feeding a scaled-up bioreactor system (Row 2 of Table 1 ). The results from the model matched well with data gathered from Electrochaea's website namely, a system of this size will recycle 7,500 Metric Tones (MT) of $\mathrm{CO}_{2}$ per year.

\section{Task 5: Valuation of Gas Energy Storage for Grid Applications - This work was not completed.}

- Using input from SoCalGas, conduct CAISO production cost modeling, capture benefits, identify operational impacts, etc. 


\section{CRADA Modification 4}

\section{Task 1: Develop Test Plan to Characterize Bioreactor Steady-State Performance}

\section{Task 1a:}

- Organize meetings to capture critical parameters to be varied and ultimately the data used in final system model

The CRADA project team consisting of NREL researchers, SoCalGas project lead and project coordinator, and Electrochaea researchers met weekly to discuss the research plans, operational challenges, and data from the bioreactor.

\section{Task 1b:}

- Develop draft and publish final steady-state test plan to the Power-to-Gas Team

The steady state test plan involved increasing $\mathrm{H}_{2}$ and $\mathrm{CO}_{2}$ flow rates from the base operating flow rates of $0.6 \mathrm{~kg} / \mathrm{hr} \mathrm{H} 2$ and $3.2 \mathrm{~kg} / \mathrm{hr} \mathrm{CO} 2$ (25\% of design point) and increasing bioreactor pressure from $4-6$ bar to 9 bar (50\% of the design point) and then 18 bar (100\% of the design point). The following is the test plan we followed in the weeks before halting operations due to construction scheduled at the equipment site.

- Increase $\mathrm{H}_{2}$ flow rate to $1 \mathrm{~kg} / \mathrm{hr}, \mathrm{CO}_{2} 6 \mathrm{~kg} / \mathrm{hr}$ from $0.6 \mathrm{~kg} / \mathrm{hr} \mathrm{H}_{2}$ and $3.2 \mathrm{~kg} / \mathrm{hr} \mathrm{CO}_{2}$

- Continue increasing $\mathrm{H}_{2}$ flow to $2.5 \mathrm{~kg} / \mathrm{hr}$ and $\mathrm{CO}_{2}$ to $13 \mathrm{~kg} / \mathrm{hr}$. Increase pressure to 9 bar (130 psig) until steady state is reached $\left(\mathrm{CH}_{4}\right.$ concentration is $>90 \%$ and constant for $2-3$ hours)

- Increase bioreactor pressure to 260 psig (18 bar) to establish steady state $\mathrm{CH}_{4}$ production at $>90 \%$.

\section{Task 2: Execute Relevant Steady-State Test Plan at Bench Scale and Produce Inoculum}

\section{Task 2a:}

- Complete bench-scale bioreactor installation and start up at ESIF

- Report on results and recommendations

A bench-scale bioreactor system was installed in a walk-in hooded space located in an ESIF laboratory with the goal of transferring the Electrochaea technology to NREL (media preparations, inoculation procedure, and fermentation protocols) and to operate the system continuously to produce 20 gallons of inoculum for the SoCalGas bioreactor start-up. The system (Figure 5) was comprised of:

- New Brunswick Bioflo 3000 fermentor with 5L vessel and controller (borrowed from the National Bioenergy Center's bench-scale fermentation laboratory)

- Two mass flow meters to deliver hydrogen and carbon dioxide from pressurized gas cylinders to the fermentor 
- Three feed bottles with peristaltic pumps to deliver sodium sulfide, salts/trace minerals, and a mixture of ammonium hydroxide and antifoam to the fermentor

- Harvest line with peristaltic pump to remove excess volume from water produced during the biomethanation chemical process

- Gas chromatograph with gas drying installed on the fermentor exhaust to measure methane, hydrogen, and carbon dioxide.

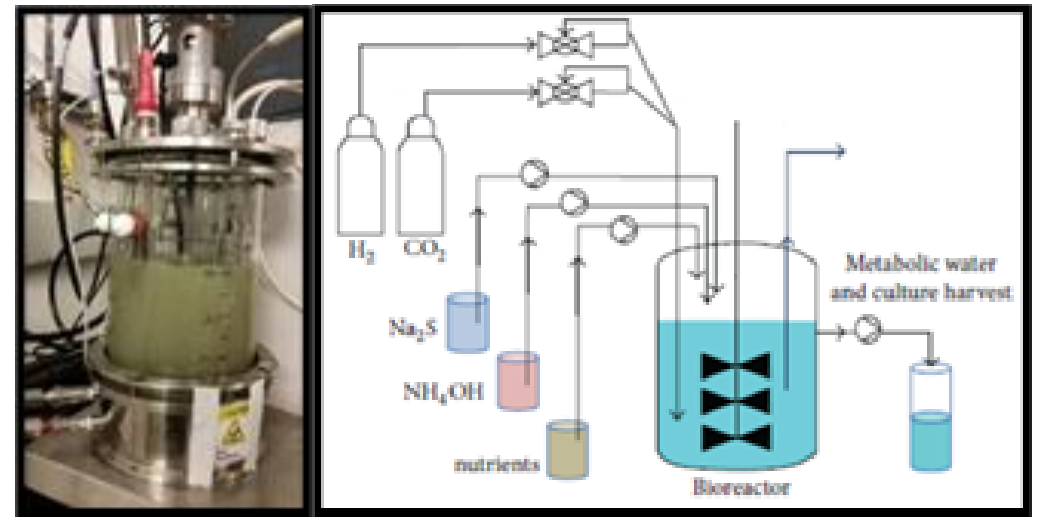

Figure $5.5 \mathrm{~L}$ bench scale ambient pressure bioreactor operating at NREL (left) and a schematic of the $5 \mathrm{~L}$ system used to accumulate inoculum for commissioning of the $700 \mathrm{~L} 18$ bar SoCal Gas reactor (right).

In preparation for operating the bench-scale system, a biosafety permit and safe operating procedure (SOP) were issued. The SOP and readiness verification of the system identified the biological, chemical, flammable, and high-pressure hazards of the system and the controls needed to minimize the risks. The protocols and SOP for the bench-scale system were used in the commissioning of the 700L SoCalGas system. The bench-scale fermentor operated continuously from August 2017 through October 2017 (1800 hours).

Task 2b:

- Perform steady-state operation of the bench-scale system by varying eligible parameters from the test plan of Task 1.

- Report on results and recommendations

A safe operating procedure (SOP) was developed after installing a benchtop fermentation system and completing hazards analysis and readiness verification with NREL's Environmental Safety and Health personnel. Once the SOP was approved, NREL researchers operated the Bioflo 3000 $5 \mathrm{~L}$ ambient pressure reactor for 1800 consecutive hours at different input gas flow rates (maximum of $550 \mathrm{~mL} / \mathrm{min} \mathrm{H}_{2}$ and $130 \mathrm{~mL} / \mathrm{min} \mathrm{CO}_{2}$ ) and nutrient feed rates. The continuous operation produced enough inoculum (20 gallons) for future SoCalGas bioreactor commissioning. This work was done at atmospheric pressure which was not optimized for gas fermentations but did demonstrate conversion efficiencies and provide data on nutrient feed rates as a function of cell mass produced. This information informed the operation of the SoCalGas bioreactor system. Figure 6 provides a snapshot of the 1800-hour run. The step-like changes in gas concentration and conversion are due to changes in $\mathrm{H}_{2}$ and $\mathrm{CO}_{2}$ feed flow rates and ratio $\left(\mathrm{H}_{2}: \mathrm{CO}_{2}\right)$. A ratio above the stochiometric ratio of $4: 1$ increases the conversion but results in 
higher loss of unconverted $\mathrm{H}_{2}$ in the off-gas. An excessive $\mathrm{H}_{2}$ gas flow rate was needed for $>$ $95 \%$ conversion of $\mathrm{CO}_{2}$ to $\mathrm{CH}_{4}$ due to poor $\mathrm{H}_{2}$ mass transfer in the liquid. At the highest feed gas flow rate, the fermentor productivity was in the range of $0.3 \mathrm{~g} \mathrm{CH}_{4} / \mathrm{L}-\mathrm{hr}$. Operating at higher pressure is a unique feature of the SoCalGas bioreactor, which is expected to increase productivity and maintain high conversion (> $97 \% \mathrm{CO}_{2}$ to $\mathrm{CH}_{4}$ ) as well as provide valuable insight on gas mass transfer.

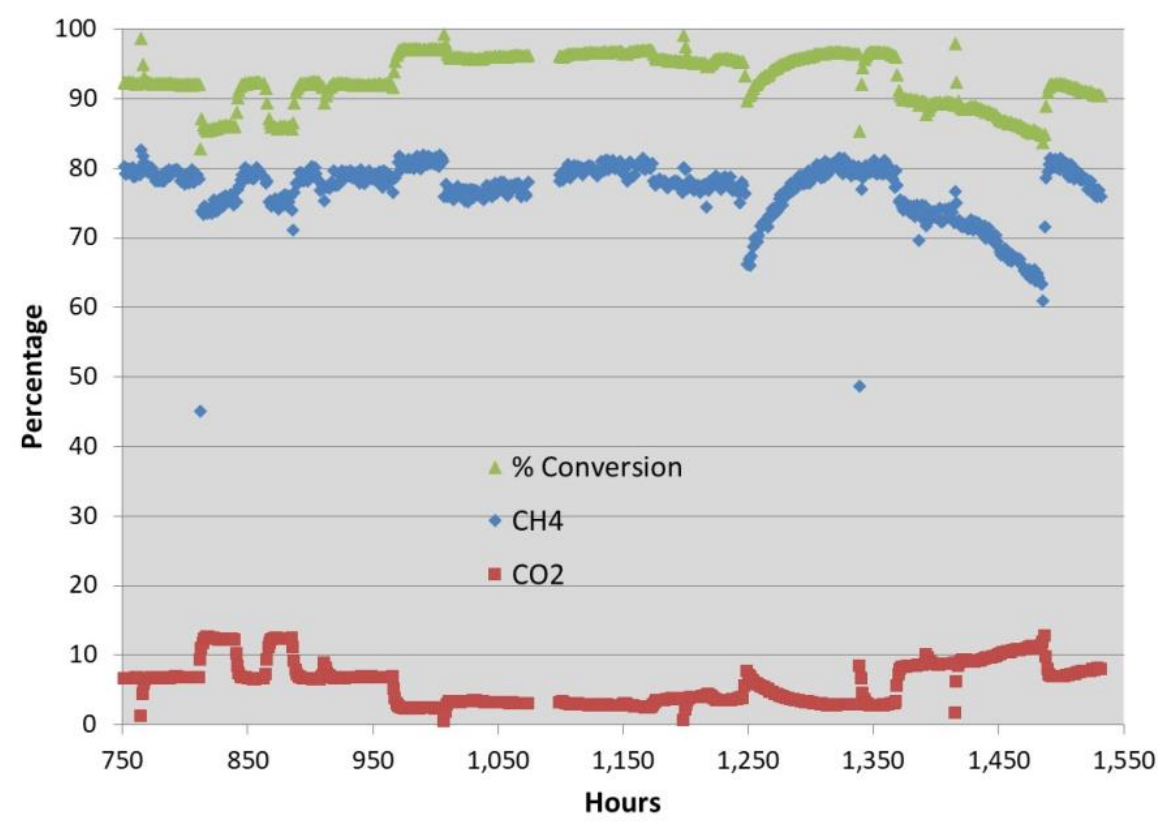

Figure 6. Time course data showing percent conversion (green), and percent $\mathrm{CO}_{2}$ (red) and $\mathrm{CH}_{4}$ (blue) in the off-gas from an 1800-hour fermentation trial using the $5 \mathrm{~L}$ bioreactor.

\section{Task 2c: Produce Inoculum}

- Accumulate at least 20 gallons of the culture broth for start-up of the bioreactor system. Completed

- Report on results and recommendations - Completed

The 5L bench-scale bioreactor operated for 1800 consecutive hours during which time water was produced during the biological conversion of $\mathrm{H}_{2}$ and $\mathrm{CO}_{2}$ to $\mathrm{CH}_{4}$. The accumulated water along with some of the culture was removed daily from the bioreactor and stored in carboys for the SoCalGas bioreactor start-up. We produced 20 gallons total.

\section{Task 3: Execute Steady-State Test Plan on SoCalGas Bioreactor System}

We successfully moved from the baseline operating conditions of $0.6 \mathrm{~kg} / \mathrm{hr} \mathrm{H} \mathrm{H}_{2}$ and $3.2 \mathrm{~kg} / \mathrm{hr} \mathrm{CO}_{2}$ gas flow rates and $90 \mathrm{psig}$ ( $6 \mathrm{bar}$ ) to $1.2 \mathrm{~kg} / \mathrm{hr} \mathrm{H} \mathrm{H}_{2}$ and $6.5 \mathrm{~kg} / \mathrm{hr} \mathrm{CO} 2$ gas flow rates and $130 \mathrm{psig}$ ( 9 bar) operations (50\% of design point). Figure 7 (A) shows the gas composition produced at these conditions. Methane concentration was above $90 \%, \mathrm{CO}_{2}$ below $1 \%$, and $\mathrm{H}_{2}$ below $10 \%$. Conversion efficiency was above 98\% during the five hours of runtime. Figure 7 (B) shows the gas composition after the $\mathrm{H}_{2}$ gas flow rate was increased to $1.5 \mathrm{~kg} / \mathrm{hr}$ and the $\mathrm{CO}_{2}$ gas flow rate 
was increased to $8 \mathrm{~kg} / \mathrm{hr}$ (continuing to maintain a $4.1 \mathrm{CO}_{2}: 1 \mathrm{H}_{2}$ volumetric gas ratio). We saw a decrease in $\mathrm{CH}_{4}$ production to $85 \%$ with recovery to $90 \%$ after 5 hours of operation. $\mathrm{CO}_{2}$ concentration increased to $4 \%$ and then fell to $1 \%$ as the process recovered from the gas flow rate changes. Conversion efficiency fell to around $95 \%$ but recovered to above $98 \%$. When we further increased the $\mathrm{H}_{2}$ gas flow rate to $2 \mathrm{~kg} / \mathrm{hr}$ and the $\mathrm{CO}_{2}$ to $10.7 \mathrm{~kg} / \mathrm{hr}$ (still maintaining the $4.1 \mathrm{CO}_{2}: 1 \mathrm{H}_{2}$ volumetric gas ratio), $\mathrm{CH}_{4}$ dropped rapidly to $60 \%$ but recovered to $90 \%$ briefly before leveling off at $35 \%$ concentration. Carbon dioxide concentrations rose to around $13 \%$ and $\mathrm{H}_{2}$ concentration increased to $50 \%$. Conversion efficiency dropped to $75 \%$ Figure 7 (C). We were unable to recover the fermentation before shutting down the bioreactor for a planned longterm construction project that required power be turned off to the construction area where the bioreactor is located.

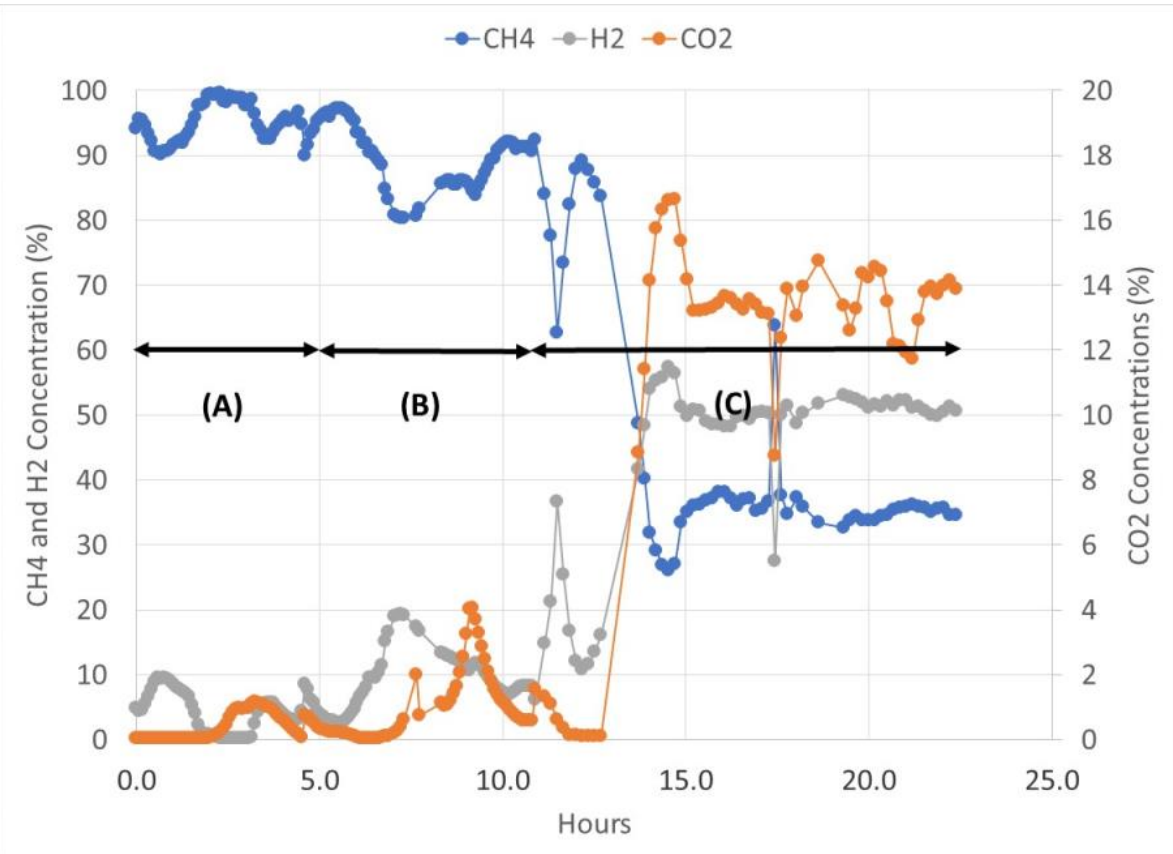

Figure 7. Composition of the product gas from the SoCalGas bioreactor over a 24-hour period of operation when gas flow rates were increased from $0.6 \mathrm{~kg} / \mathrm{hr} \mathrm{H} 2$ and $3.2 \mathrm{~kg} / \mathrm{hr} \mathrm{CO} 2$ to $2 \mathrm{~kg} / \mathrm{hr} \mathrm{H} 2$ and $10.6 \mathrm{~kg} / \mathrm{hr} \mathrm{CO}$. Bioreactor pressure was constant at $130 \mathrm{psig}(9 \mathrm{bar})$.

\section{Lessons Learned}

We experienced several issues while operating the bioreactor and the nutrient dosing equipment that prevented us from achieving steady state above $2 \mathrm{~kg} / \mathrm{hr} \mathrm{H}_{2}$ gas flow rate and 130 psig and completing the full test plan. We had problems with dosing nutrients reliably to the biocatalyst. While this did not seem a problem during start-up because of low gas flow rates and excess nutrients that were batched at start-up, the higher gas flow rates with higher conversion meant more water was produced requiring more frequent replenishing of the trace elements, salts, nitrogen, and sulfur. The over-sized nutrient tanks did not allow for easy monitoring of volumes over many days of operation. No load cells or in-line flow meters to monitor feed rates were designed into the system. The pumps did not deliver a consistent volume as the pressure in the bioreactor was increased. The culture was likely, at times, starved for one or more nutrients. The upsets in nutrient addition caused foaming in the bioreactor. This is a common occurrence in 
biological fermentations and can be controlled by adding an antifoam (surfactant). We were prepared to add antifoam, but the installed pump was not able to pump the viscous antifoam into the bioreactor against the pressure. The location of the antifoam addition port on the bioreactor was problematic. The antifoam was added above the liquid level but along the wall of the bioreactor which did not disperse the foam. The antifoam needs to be added directly over the foam to be effective. Foaming is highly disruptive to the system, causing uncontrolled losses in volume to the waste tank. Large losses in liquid also meant losses in biocatalyst numbers which required the addition of more nutrients. Thus, we did not achieve the biocatalyst numbers needed for converting the higher gas feed rates. For reference, biocatalyst numbers were half that achieved in the $5 \mathrm{~L}$ bench-scale bioreactor.

The high conversion rate of $\mathrm{CO}_{2}$ and $\mathrm{H}_{2}$ to $\mathrm{CH}_{4}$ at the lower gas flow rates show the potential of the biomethanation process. We are confident that when we resume operations, we will be able to improve the operability of the nutrient dosing system to achieve the gas flow rates and pressure for which the bioreactor was designed.

\section{Task 4: Develop Test Plan for Variable Mode of Bioreactor Operations}

Variable mode test plan:

- Establish $\mathrm{H}_{2}$ gas flow at $1 \mathrm{~kg} / \mathrm{hr}$

- Increase flow in increments of $0.2 \mathrm{~kg} / \mathrm{hr}$, holding at each new flow rate for 2-3 hours to establish a new equilibrium state before increasing gas flowrate again.

- Once $2 \mathrm{~kg} / \mathrm{hr}$ is achieved, decrease the $\mathrm{H} 2$ gas flow down to $1 \mathrm{~kg} / \mathrm{hr}$ in one step

- Monitor input gas flowrates from the Coriolis mass flowmeter to validate the 4:1 $\mathrm{H}_{2}: \mathrm{CO}_{2}$ ratio is maintained.

\section{Task 5: Execute Test Plan for Variable Mode of Bioreactor Operations}

We could demonstrate variable mode of operation in the bioreactor by changing the $\mathrm{H}_{2}$ gas flow rate over a 15-hour period of time, matching the $\mathrm{CO}_{2}$ flow rate to maintain a 4:1 $\mathrm{H}_{2}$ to $\mathrm{CO}_{2}$ volumetric gas ratio in the feed gas. Controlling the $\mathrm{H}_{2}$ flow rate is challenging because of the low density of the gas, even when using a Coriolis mass flow meter. Figure 8 shows the flow rates of $\mathrm{H}_{2}$ and $\mathrm{CO}_{2}$ with the gas ratio during 15 hours of operation in the SoCalGas bioreactor. The bioreactor parameters were $60^{\circ} \mathrm{C}, \mathrm{pH}$ of 7 , and $130 \mathrm{psig}$ (9 bar) pressure. The $\mathrm{H}_{2}$ concentration was fairly stable at each setpoint, though this required close monitoring of the input pressure of the feed gas to maintain an optimal differential pressure across the flow meter.

As the $\mathrm{H}_{2}$ flow rate was increased, the $\mathrm{CO}_{2}$ flow rate was also increased to maintain the 4:1 volumetric gas ratio. Each change in flow was followed by a reduction in conversion then recovery of the $\mathrm{CH}_{4}$ concentration in the product gas. A stable steady state was reached for three hours at $1.8 \mathrm{~kg} / \mathrm{hr} \mathrm{H}$ and $10.5 \mathrm{~kg} / \mathrm{hr} \mathrm{CO}$ gas feed rate. The $\mathrm{CH}_{4}$ concentration in the product gas stayed steady at $98 \%$. Subsequent changes in gas flows and gas ratio reduced the $\mathrm{CH}_{4}$ concentration briefly until the system recovered to $98 \% \mathrm{CH}_{4}$ concentration in the product gas. 


\section{Key Finding}

During operations, we could maintain constant $\mathrm{H}_{2}$ and $\mathrm{CO}_{2}$ gas flow rates for a consistent product gas that meets pipeline specifications. However, if the electrolyzer is load following renewable electricity supply and the $\mathrm{H}_{2}$ flow rate becomes variable, it is possible to adjust the $\mathrm{CO}_{2}$ gas flow rate to maintain $\mathrm{CH}_{4}$ concentrations. The time it takes to stabilize the system will get faster with operational experience.

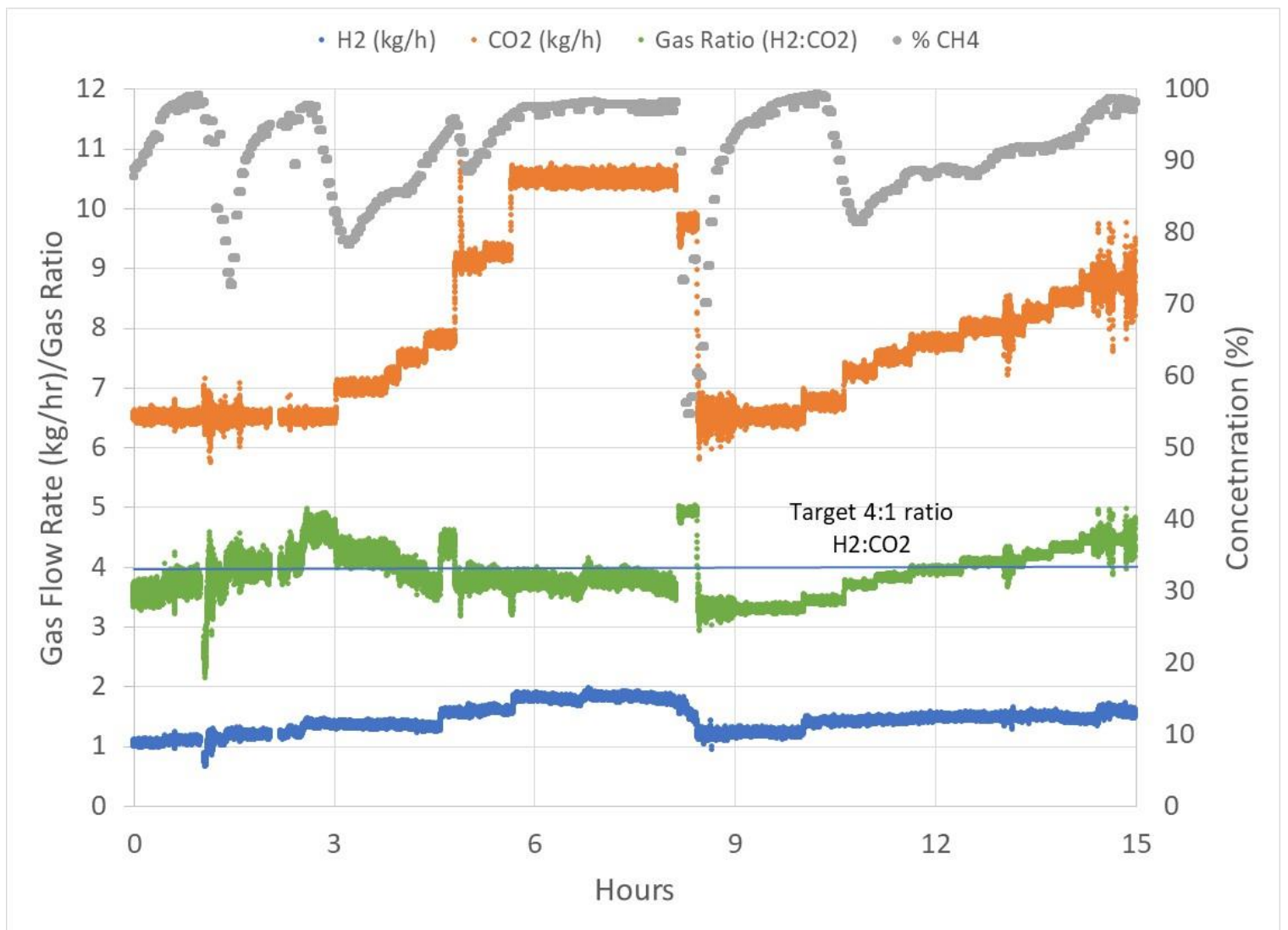

Figure 8. Operational data $\left(\mathrm{H}_{2}\right.$ and $\mathrm{CO}_{2}$ gas flow rates, gas ratio, and $\mathrm{CH}_{4}$ concentration in the product gas) from the SoCalGas bioreactor during 15 hours of variable operation is shown. The bioreactor temperature and $\mathrm{pH}$ were controlled at $60^{\circ} \mathrm{C}$ and 7 , respectively. The pressure in the bioreactor was 130 psig (9 bar).

\section{Task 6: Modeling and Analysis}

A solar-to-methane scoping study was performed to investigate the levelized cost of methane (LCOM) resulting from different envisioned operational scenarios and timeframes. The goal of this analysis was to identify specific technology performance and cost targets that would enable a glidepath from today's capabilities to operational scenarios based on expected future performance. The examined system included a PV solar subsystem to generate renewable electricity to power a PEM electrolyzer for the production of hydrogen. The option for hydrogen storage was investigated in one operational scenario to understand the cost impact of decoupling the PEM electrolyzer from the grid. The generated $\mathrm{H}_{2}$ would subsequently be fed to a bioreactor in combination with $\mathrm{CO}_{2}$ collected from a co-located point source to biologically produce 
methane. Additionally, efforts were made to align analysis inputs in this study with previously published values from the Annual Technology Baseline (ATB), Multi-Year Research, Development, and Demonstration (MYRD\&D) Plan and State of Technology (SOT) assessments to provide a bridge connecting existing analyses from the Solar Energy Technology Office (SETO), Hydrogen and Fuel Cell Technology Office (HFTO) and Bioenergy Technology Office (BETO).

It should be emphasized that the RNG market is the targeted outlet for this methane product, as opposed to the fossil-based natural gas market. Thus, an RNG production cost target of 15 \$/MMBTU was selected for future operational scenarios. As summarized in Table ES-1, it is envisioned that an overall 15 \$MMBTU cost target can be approached with the future cost targets of $19 \$ / \mathrm{MWh}$ for levelized cost of energy (LCOE), $1.26 \$ / \mathrm{kg}-\mathrm{H}_{2}$ for levelized cost of hydrogen $(\mathrm{LCOH})$, and $0.35 \$ / \mathrm{kg}-\mathrm{H}_{2}$ for levelized cost of bioreactor (LCOB).

Table ES-1: Summary of analysis results showing one possible glidepath for this solar-to-methane system from today's capabilities to approach an RNG production cost of 15 \$/MMBTU.

\begin{tabular}{|c|c|c|c|c|c|}
\hline & Units & $\begin{array}{c}\text { Current } \\
\text { (with } \mathrm{H}_{2} \\
\text { Storage) }\end{array}$ & $\begin{array}{c}\text { Current } \\
\text { (with Grid } \\
\text { Support) }\end{array}$ & $\begin{array}{l}\text { Expected } \\
\text { Future } \\
\text { Performance }\end{array}$ & $\begin{array}{l}\text { Proposed } \\
\text { Targets to } \\
\text { Approach } 15 \\
\text { \$/MMBTU } \\
\text { RNG }^{4}\end{array}$ \\
\hline LCOE & [\$/MWh] & 75 & 75 & 29 & 19 \\
\hline H2 Storage Costs & [\$/kg-H2] & 1.75 & 0 & 0 & 0 \\
\hline $\begin{array}{l}\text { LCOH (Including } \\
\text { H2 Storage Costs) }\end{array}$ & [\$/kg-H2] & 7.50 & 5.10 & 2.06 & 1.26 \\
\hline LCOB & [\$/kg-H2] & 0.59 & 0.63 & 0.39 & 0.35 \\
\hline LCOM & [\$/MMBTU] & 88.97 & 54.58 & 23.34 & 15.34 \\
\hline
\end{tabular}

\section{Task 6: Modeling and Analysis - Key Assumptions}

${ }^{1}$ Levelized Cost of Energy (LCOE): Aligned with 2017 baseline ATB LCOE for Comm PV - Los Angeles - Low; $\mathrm{H}_{2}$ Storage Costs: Included in LCOH as compression and tank storage; Levelized Cost of Hydrogen ( $\mathrm{LCOH}$ ): PEM electrolyzer subsystem cost at $\$ 1000 / \mathrm{kW}$ with total electrical usage of $55.8 \mathrm{kWh} / \mathrm{kg}-\mathrm{H}_{2}$ and $20 \%$ capacity factor; Levelized Cost of Bioreactor ( $L C O B)$ : Calculated from Electrochaea $\mathrm{GmbH}$ bioreactor cost data and demonstrated $\mathrm{CH}_{4}$ productivity of $12.5 \mathrm{~g}-\mathrm{CH}_{4} / \mathrm{L} / \mathrm{hr}$; Levelized Cost of Methane (LCOM): Calculated using conversion factors of $\mathrm{CH}_{4} \mathrm{HHV}=55.38 \mathrm{MJ} / \mathrm{kg}$ and $1 \mathrm{MJ}=947.82 \mathrm{BTU}$.

${ }^{2}$ LCOE: Same as ${ }^{1} ; \mathrm{H}_{2}$ Storage Costs: Assumed zero and that grid electricity is used at cost parity when PV electricity is not directly available to increase PEM electrolyzer capacity factor to $90 \%$; $L C O H$ : PEM electrolyzer subsystem cost at $\$ 1000 / \mathrm{kg}-\mathrm{H}_{2}$ with total electrical usage of $55.8 \mathrm{kWh} / \mathrm{kg}-\mathrm{H}_{2}$ and $90 \%$ capacity factor; $L C O B$ : Same as ${ }^{1} ;$ LCOM: Same as ${ }^{1}$. 
${ }^{3}$ LCOE: Aligned with 2030 ATB LCOE for Comm PV - Los Angeles - Low; $\mathrm{H}_{2}$ Storage Costs: Same as ${ }^{2}$; $L C O H$ : PEM electrolyzer subsystem cost at $\$ 450 / \mathrm{kW}$ with total electrical usage of $51.4 \mathrm{kWh} / \mathrm{kg}-\mathrm{H}_{2}$ and $90 \%$ capacity factor; $L C O B$ : Calculated from Electrochaea $\mathrm{GmbH}$ bioreactor cost data and expected future $\mathrm{CH}_{4}$ productivity of $25 \mathrm{~g}-\mathrm{CH}_{4} / \mathrm{L} / \mathrm{hr} ; \mathrm{LCOM}$ : Same as ${ }^{1}$. ${ }^{4}$ LCOE: Aligned with 2050 ATB LCOE for Comm PV - Los Angeles - Low; $\mathrm{H}_{2}$ Storage Costs: Same as ${ }^{2}$; $L C O H$ : PEM electrolyzer subsystem cost at $\$ 200 / \mathrm{kg}-\mathrm{H}_{2}$ with total electrical usage of $50.2 \mathrm{kWh} / \mathrm{kg}-\mathrm{H}_{2}$ and $90 \%$ capacity factor; $L C O B$ : Calculated from Electrochaea $\mathrm{GmbH}$ bioreactor cost data and expected future $\mathrm{CH}_{4}$ productivity of $30 \mathrm{~g}-\mathrm{CH}_{4} / \mathrm{L} / \mathrm{hr} ;$ LCOM: Same as ${ }^{1}$.

\section{ROI \#:}

- NREL Record of Inventions (ROIs) No. 18-48, 18-48A and 19-140

\section{Subject Invention:}

- The international ("PCT") patent application corresponding to NREL Record of Invention No. 18-48 was published by the World Intellectual Property Office (WIPO). Relevant data for this patent application are below:

- Publication No.: WO 2020/018998 A1

- Application No.: PCT/US19/42861

- Filing Date: July 22, 2019

- May 2020: SoCalGas entered into exclusive licensing agreement for IP developed under NREL ROI 18-48 and 18-48A

- The U.S. provisional patent application corresponding to NREL Record of Invention (ROI) No. 19-140 was filed on August 7, 2020 at the United States Patent \& Trademark Office (USPTO) and has received Application No. 63/063,000.

- The U.S. non-provisional patent application (371 National Stage Application) corresponding to NREL Record of Invention (ROI) No. 18-48 was filed on January 19, 2021 at the United States Patent \& Trademark Office (USPTO) and has received Application No. 17/261,473. 